\title{
HUBUNGAN ANTARA PERILAKU MEROKOK PADA ORANG TUA DENGAN KEJADIAN INFEKSI SALURAN PERNAPASAN ATAS (ISPA) PADA ANAK SEKOLAH DASAR USIA 7-12 TAHUN DI PUSKESMAS PORONG
}

\author{
Aisyah Rachmawati \\ M.E. Winarno \\ Septa Katmawanti \\ Fakultas Ilmu Keolahragaan Univesitas Negeri Malang \\ email: aisyahrachmawati94@gmail.com
}

\begin{abstract}
Smoking is an unhealthy behavior that has been common thing in the society. In 2013, noted that the smoker reach $36.3 \%$ in number while smoking cause respiration problems, one of it is respiration problem. In 2013, East Java became one of province with highest ISPA case. This study as a purpose to find the relationship between smoking behavior in the parents with the incidence of ISPA in elementary children in Porong Primary Health Care with the working hypothesis is there is a significant relationship between variables. This research uses correlational quantitative research design with 115 samples. Data analysis is using Spearman Rank test. The sampling technique used is Purposive Sampling. Technique of collecting data is using questionnaire. Instrument used to collect data in the form of human instruments, namely researchers herself. Data analysis activities started from the preparation stage, data collection, data entry, data analysis, and hypothetical test.

The result of research based on item score found there is significant correlation in result of hypothesis test with $P$ value $(0.00)<\alpha(0.05)$ with correlation coefficient ( $r$ ) obtained is 0.588 .
\end{abstract}

Keywords: Smoking Behavior, Upper Respiratory Infection, Porong Primary Health Care

\begin{abstract}
Abstrak: Merokok adalah perilaku tidak sehat yang telah dianggap biasa oleh masyarakat. Pada tahun 2013 tercatat bahwa jumlah perokok mencapai 36,3\% sedangkan, merokok menyebabkan berbagai permasalahan kesehatan, salah satunya adalah masalah pernapasan. Pada tahun 2013, Jawa Timur menjadi salah satu provinsi dengan ISPA tertinggi. Penelitian ini dilaksanakan dengan tujuan untuk mencari hubungan antara perilaku merokok pada orang tua dengan kejadian ISPA pada anak sekolah dasar di Puskesmas Porong dengan hipotesis kerja adalah ada hubungan yang signifikan antar variabel. Rancangan penelitian ini adalah kuantitatif korelasional dengan sampel sebanyak 115 orang. Analisis data menggunakan uji Spearman Rank Test. Teknik pengambilan sampel yang digunakan adalah Purposive Sampling. Teknik pengumpulan data menggunakan metode kuesioner. Instrumen yang digunakan untuk mengumpulkan data berupa instrumen manusia, yaitu peneliti sendiri. Kegiatan analisis data dimulai dari tahap persiapan, pengambilan data, entry data, analisis data, dan pengujian hipotesis. Hasil penelitian berdasarkan nilai skor butir pertanyaan didapatkan ada hubungan yang signifikan dalam hasil uji hipotesis dengan nilai $\mathrm{P}(0,00)<\alpha(0,05)$ dengan koefisien korelasi (r) yang didapatkan adalah 0,588 .
\end{abstract}

Kata kunci: Perilaku Merokok, Infeksi Saluran Pernapasan Atas, Puskesmas Porong 
Merokok adalah perilaku yang masih banyak dilakukan oleh masyarakat hingga saat ini. Padahal, merokok menyumbang risiko kematian yang besar. Disamping itu, kebiasaan merokok merupakan kebiasaan yang sulit untuk dihentikan. Bahkan, tanpa disadari merokok menjadi perilaku yang membudaya di Indonesia. Menurut laporan Badan Penelitian dan Pengembangan Kesehatan Kementerian Kesehatan RI, Riskesdas (2013), proporsi penduduk umur $\geq 15$ tahun yang merokok cenderung meningkat yaitu dalam Riskesdas tahun 2007 sebesar 34,2\%, Riskesdas tahun 2010 sebesar 34,7\% dan Riskesdas tahun 2013 sebesar 36,3\%. Jumlah tersebut masih belum terjadi penurunan dari 2007 ke 2013.

Sebagai upaya menanggulangi jumlah perokok, pemerintah telah membuat kebijakan yaitu adanya kewajiban setiap produsen rokok menggunakan gambar penyakit kronis pada kemasan rokok, meningkatkan besar cukai rokok, hingga fatwa haram merokok oleh Majelis Ulama Indonesia (MUI). Namun, upaya-upaya tersebut seperti kurang efektif dalam mencapai tujuannya. Nyatanya, jumlah perokok belum pernah mengalami penurunan.

Forum of International Respiratory Societies (2013), asap tembakau menyebabkan salah satunya kerusakan jaringan paru-paru dan obstruksi dari saluran udara kecil. New York State Department of Health (2014) mengemukakan bahwa pada bayi dan anak-anak sebagai non-perokok, asap rokok menyebabkan berbagai masalah kesehatansalah satunya adalah infeksi pernapasan. Meskipun tidak menghisap rokok secara langsung, zat kotinin yang ditemukan pada perokok aktif juga ditemukan pada tubuh perokok pasif. Di Amerika Serikat, anak-anak usia 3 hingga 11 tahun memiliki konsentrasi serum cotinine (pemecah nikotin) yang lebih dari dua kali lebih tinggi dari orang dewasa yang tidak merokok (CDC, 2007). Hal ini berarti mereka yang tidak tinggal dengan perokok pun juga mungkin berisiko terkena efek buruk dari asap rokok.

Sementara itu, anak-anak memiliki sistem kekebalan yang tidak sama dengan orang dewasa, dalam hal ini anak-anak lebih rentan terkena sakit.

Menurut Riskesdas (2013), Jawa Timur tergolong dalam lima provinsi dengan ISPA tertinggi. Di Puskesmas Porong, ISPA juga hampir selalu menjadi peringkat pertama masuk pada 10 penyakit terbanyak. Tahun 2015, kasus ISPA berjumlah 26.113 sedangkan tahun 2016, jumlah kasus ISPA meningkat hampir dua kali lipat menjadi 47.323 kasus.

Anak usia sekolah dasar yaitu anak usia 7-12 tahun adalah masa-masa peralihan dimana mereka mulai belajar mandiri dan mengenal lingkungan lebih luas. Pada anak sekolah dasar, peran orang tua cenderung berimbang antara ayah dan ibu dan lingkungan menjadi faktor yang cukup besar mempengaruhi kesehatannya.

Berdasarkan latar belakang yang diuraikan di atas, maka penulis tertarik untuk mengetahui hubungan antara perilaku merokok pada orang tua dengan kejadian ISPA pada anak sekolah dasar. Sehingga penulis dapat mewujudkan kegunaan dalam penelitian ini untuk memberikan masukan dan pertimbangan kepada orang tua dalam peningkatan derajat kesehatan anak dan anggota keluarga lainnya.

\section{METODE}

Metode penelitian yang digunakan adalah penelitian kuantitatif korelasional. Variabel bebas dalam penelitian ini adalah perilaku merokok, sedangkan variabel terikat adalah kejadian ISPA. Sampel dalam penelitian ini adalah pengunjung puskesmas Porong yang memenuhi kriteria yang berjumlah 115 responden. Pengumpulan data dalam penelitian ini menggunakan kuesioner dengan teknik sampling yang digunakan adalah purposive sampling. Jadwal waktu pelaksanaan pengumpulan data dilaksanakan pada tanggal 7 Pebruari 2017 sampai dengan 7 Maret 2017. 
Analisis data yang digunakan adalah uji korelasi Spearman Rank.
HASIL PENELITIAN tabel berikut.
Hasil penelitian disajikan pada

Tabel 1 Pendidikan Terakhir Responden

\begin{tabular}{lcc}
\multicolumn{1}{c}{ Pendidikan Terakhir } & \multicolumn{2}{c}{ Jawaban } \\
\cline { 2 - 3 } & f & \% \\
\hline Tamat Akademi/sederajat & 2 & 1,7 \\
Tamat SMU/sederajat & 10 & 8,7 \\
Tamat SMP/sederajat & 21 & 18,3 \\
Tamat SD/sederajat & 62 & 53,9 \\
Tidak Tamat Sekolah Formal & 20 & 17,4 \\
\hline
\end{tabular}

Tabel 1 menunjukkan bahwa sedangkan tamat akademi/sederajat sebagian besar responden mimiliki pendidikan rendah yaitu $62 \%$ tamat $S D$,

Tabel 2 Data Hasil Kuesioner Perilaku Merokok pada Orang Tua

\begin{tabular}{|c|c|c|c|c|c|c|c|c|}
\hline \multirow{3}{*}{ Pernyataan } & \multicolumn{8}{|c|}{ Jawaban } \\
\hline & \multicolumn{2}{|c|}{ Skor 1} & \multicolumn{2}{|c|}{ Skor 2} & \multicolumn{2}{|c|}{ Skor 3} & \multicolumn{2}{|c|}{ Skor 4} \\
\hline & f & $\%$ & f & $\%$ & $\mathbf{f}$ & $\%$ & f & $\%$ \\
\hline $\begin{array}{l}\text { Anda atau pasangan } \\
\text { merokok }\end{array}$ & 47 & 40,9 & 10 & 8,7 & 7 & 6,1 & 51 & 44,3 \\
\hline $\begin{array}{l}\text { Anda atau pasangan Anda } \\
\text { merokok didekat anak }\end{array}$ & 70 & 60,9 & 37 & 32,2 & 5 & 4,3 & 3 & 2,6 \\
\hline $\begin{array}{l}\text { Ketika anak Anda sakit, Anda } \\
\text { menjauhkannya dari asap rokok }\end{array}$ & 97 & 84,3 & 9 & 7,8 & 3 & 2,6 & 6 & 5,2 \\
\hline $\begin{array}{lcc}\text { Anda atau pasangan } & \text { Anda } \\
\text { merokok } & \text { di } & \text { dalam } \\
\text { rumah/sekitarnya } & \end{array}$ & 55 & 47,8 & 49 & 42,6 & 5 & 4,3 & 6 & 5,2 \\
\hline $\begin{array}{l}\text { Anda atau pasangan Anda } \\
\text { merokok setiap pagi }\end{array}$ & 52 & 45,2 & 29 & 25,2 & 28 & 24,3 & 6 & 5,2 \\
\hline $\begin{array}{l}\text { Anda atau pasangan Anda } \\
\text { merokok setiap siang }\end{array}$ & 47 & 40,9 & 26 & 22,6 & 30 & 26,1 & 12 & 10,4 \\
\hline $\begin{array}{l}\text { Anda atau pasangan Anda } \\
\text { merokok setiap malam }\end{array}$ & 48 & 41,7 & 20 & 17,4 & 34 & 29,6 & 13 & 11,3 \\
\hline $\begin{array}{l}\text { Frekuensi Anda atau pasangan } \\
\text { Anda merokok dalam seminggu }\end{array}$ & 47 & 40,9 & 7 & 6,1 & 12 & 10,4 & 49 & 42,6 \\
\hline $\begin{array}{l}\text { Intensitas Anda atau pasangan } \\
\text { Anda merokok setiap hari }\end{array}$ & 47 & 40,9 & 14 & 12,2 & 13 & 11,3 & 41 & 35,7 \\
\hline $\begin{array}{l}\text { Frekuensi rokok yang Anda atau } \\
\text { pasangan Anda habiskan dalam } \\
\text { sehari }\end{array}$ & 47 & 40,9 & 16 & 13,9 & 10 & 8,7 & 42 & 36,5 \\
\hline $\begin{array}{l}\text { Durasi Anda atau pasangan } \\
\text { Anda sekali merokok }\end{array}$ & 47 & 40,9 & 27 & 23,5 & 40 & 34,8 & 1 & 0,9 \\
\hline $\begin{array}{l}\text { Lama Anda atau pasangan Anda } \\
\text { telah merokok }\end{array}$ & 47 & 40,9 & 1 & 0,9 & 9 & 7,8 & 58 & 50,4 \\
\hline
\end{tabular}

Tabel 2 menunjukkan bahwa sebagian besar responden memiliki kebiasaan merokok yaitu sebesar $59,1 \%$ sedangkan 40,9\% tidak merokok. Kemudian, menurut tabel tersebut respon orang tua terhadap asap rokok ketika ada anak di sekitarnya sebagian besar responden menjauhkan anak mereka dari asap rokok yaitu sebesar $60,9 \%$ perokok yang tidak merokok di dekat anak dan $84,3 \%$ responden menjauhkan anak mereka dari asap rokok. Perokok paling sering merokok di malam hari yaitu sebesar $29,6 \%$ dan merokok lebih dari 7 kali dalam sehari yaitu sebesar $35,7 \%$. 
Tabel 3 Tingkat Perilaku Merokok

\begin{tabular}{lcc}
\hline \multirow{2}{*}{ Kategori } & \multicolumn{3}{c}{ Jawaban } \\
\cline { 2 - 3 } & f & \% \\
\hline Rendah & 47 & 40,9 \\
Sedang & 66 & 57,4 \\
Tinggi & 2 & 1,7 \\
\hline Sun
\end{tabular}

Sumber: Azwar, 2015:147-150

Perilaku merokok dikategorikan menjadi 3, yaitu tinggi, sedang, dan rendah. Kategori ini berdasarkan kategorisasi jenjang menurut Azwar (2015) dengan perhitungan menggunakan nilai mean dan deviasi

Tabel 4 Tipe Perokok

\begin{tabular}{lcc}
\hline \multirow{2}{*}{ Kategori } & \multicolumn{2}{c}{ Jawaban } \\
\cline { 2 - 3 } & f & \% \\
\hline $1-10$ batang (Perokok Ringan) & 16 & 23,5 \\
$11-20$ batang (Perokok Sedang) & 10 & 14,7 \\
$>21$ batang (Perokok Berat) & 42 & 61,8 \\
\hline
\end{tabular}

Perokok dibagi menjadi 3 kategori menurut WHO berdasarkan jumlah rokok yang dikonsumsi. Tabel 4 menunjukkan bahwa sebagian besar orang tua yang merokok tergolong dalam standar. Tabel 3 menunjukkan bahwa perilaku merokok $40,9 \%$ orang tua tergolong rendah; $57,4 \%$ orang tua tergolong sedang; dan $1,7 \%$ orang tua tergolong tinggi.

Tabel 5 Lama Telah Merokok (Tahun)

\begin{tabular}{cccc}
\hline & \multirow{2}{*}{ Kategori } & \multicolumn{2}{c}{ Jawaban } \\
\cline { 3 - 4 } & & f & \% \\
\hline 1-5 tahun & 1 & 1,5 \\
6-10 tahun & 9 & 13,2 \\
$>10$ tahun & 58 & 85,3 \\
\hline
\end{tabular}

Tabel 5 menunjukkan bahwa sebagian besar orang tua yang merokok telah merokok selama lebih dari 10 tahun yaitu sebesar $85 \%$. Sedangkan lainnya, perokok berat yaitu sebesar $61,8 \%$. Sedangkan lainnya, $23,5 \%$ orang tua tergolong perokok ringan dan $14,7 \%$ tergolong perokok sedang.

Tabel 6 Data Hasil Kuesioner Kejadian ISPA pada Anak

\begin{tabular}{|c|c|c|c|c|c|c|c|c|}
\hline \multirow{3}{*}{ Pernyataan } & \multicolumn{8}{|c|}{ Jawaban } \\
\hline & \multicolumn{2}{|c|}{ Skor 1} & \multicolumn{2}{|c|}{ Skor 2} & \multicolumn{2}{|c|}{ Skor 3} & \multicolumn{2}{|c|}{ Skor 4} \\
\hline & $\mathbf{f}$ & $\%$ & $\mathbf{f}$ & $\%$ & f & $\%$ & f & $\%$ \\
\hline $\begin{array}{l}\text { Anak Anda pernah menderita } \\
\text { batuk-pilek/flu }\end{array}$ & 7 & 6,1 & 61 & 53 & 45 & 39,1 & 2 & 1,7 \\
\hline $\begin{array}{l}\text { Anak Anda menderita batuk- } \\
\text { pilek juga disertai panas badan }\end{array}$ & 7 & 6,1 & 58 & 50,4 & 29 & 25,2 & 21 & 18,3 \\
\hline $\begin{array}{l}\text { Batuk-pilek disertai demam } \\
\text { tersebut sembuh dalam waktu } \\
\text { kurang dari } 2 \text { minggu/ } 14 \text { hari }\end{array}$ & 8 & 7 & 3 & 2,6 & 2 & 1,7 & 102 & 88,7 \\
\hline $\begin{array}{l}\text { Frekuensi anak Anda terkena } \\
\text { batuk-pilek demam tersebut }\end{array}$ & 8 & 7 & 54 & 47 & 45 & 39,1 & 8 & 7 \\
\hline
\end{tabular}

13,2\% telah merokok selama 6-10 tahun dan $1,5 \%$ orang tua telah merokok selama 1-5 tahun. 
Tabel 6 menunjukkan bahwa sebagian besar responden memiliki anak yang pernah mengalami ISPA yaitu sebesar $93,95 \%$ sedangkan $6,1 \%$ tidak pernah mengalami ISPA.

Tabel 7 Tingkat ISPA

\begin{tabular}{lcc}
\hline \multirow{2}{*}{ Kategori } & \multicolumn{3}{c}{ Jawaban } \\
\cline { 2 - 3 } & $\mathbf{f}$ & \% \\
\hline Rendah & 11 & 9,6 \\
Sedang & 101 & 87,8 \\
Tinggi & 3 & 2,6 \\
\hline
\end{tabular}

Sumber: Azwar, 2015

Kejadian ISPA dikategorikan menjadi 3, yaitu tinggi, sedang, dan rendah. Kategori ini berdasarkan kategorisasi jenjang menurut Azwar (2015) yaitu dengan perhitungan menggunakan nilai rata-rata dan deviasi standar. Tabel 7 menunjukkan sebagian besar anak mengalami kejadian ISPA tergolong sedang dengan besar $87,8 \%$. Sedangkan lainnya, sebesar 9,6\% anak mengalami kejadian ISPA tergolong rendah dan 2,6\% anak mengalami kejadian ISPA tergolong tinggi.

Tabel 8 Crosstabulasi Tingkat Perilaku Merokok dengan Tingkat ISPA

\begin{tabular}{cccccc}
\hline \multirow{2}{*}{ Kategori } & & \multicolumn{3}{c}{ Tingkat ISPA } & \multirow{2}{*}{ Total } \\
\cline { 3 - 5 } & & R & S & T & \\
\hline \multirow{3}{*}{ Tingkat Perilaku Merokok } & $\mathbf{R}$ & 9 & 38 & 0 & 47 \\
& $\mathbf{S}$ & 2 & 62 & 2 & 66 \\
& $\mathbf{T}$ & 0 & 1 & 1 & 2 \\
\hline
\end{tabular}

Keterangan:

R: Rendah; S: Sedang ; T: Tinggi

Tabel 8 menunjukkan bahwa sebagian besar responden memiliki tingkat kejadian ISPA anak tergolong sedang dengan tingkat perilaku merokok sedang yaitu sebanyak 62 responden atau sebesar $53,91 \%$. Sementara itu, dijumpai juga 1 responden $(0,86 \%)$ yang memiliki tingkat perilaku merokok tinggi dengan tingkat kejadian ISPA anak tinggi.

Tabel 9 Perbandingan Kejadian ISPA Anak pada Orang Tua Perokok dan Bukan Perokok

\begin{tabular}{ccccc}
\hline Aspek ISPA & Perokok & \% & Non Perokok & \% \\
\hline $\mathrm{R}$ & 2 & 2,9 & 9 & 19,1 \\
$\mathrm{~S}$ & 63 & 92,6 & 38 & 80,9 \\
$\mathrm{~T}$ & 3 & 4,4 & 0 & 0 \\
\hline
\end{tabular}

Tingkat kejadian ISPA anak pada orang tua perokok dan non-perokok berbeda. Tabel 9 menunjukkan bahwa sebagian besar kejadian ISPA anak tergolong rendah baik pada perokok maupun pada non perokok. Namun, pada perokok lebih tinggi $11,7 \%$ disbanding non perokok. Sementara itu, pada perokok juga dijumpai kejadian ISPA anak tergolong tinggi sebesar 4,4\%, sedangkan pada non perokok tidak dijumpai.

Tabel 10 One-Sample Kolmogorov-Smirnov Test

\begin{tabular}{lccc}
\hline & Merokok & ISPA \\
\hline Normal Parameters & Mean & 24,82 & 11,10 \\
\hline $\begin{array}{l}\text { Asymp. Sig. } \\
\text { (2-tailed) }\end{array}$ & $\mathbf{, 0 0 0}$ & $\mathbf{, 0 0 0}$ \\
\hline
\end{tabular}


$>0,05$ maka $\mathrm{H}_{0}$ diterima dan Ha ditolak, dan apabila nilai signifikansi ( $p$-value) $<0,05$ maka $\mathrm{H}_{0}$ ditolak dan $\mathrm{Ha}$ diterima. Dalam uji normalitas, terdapat dua hipotesis, yaitu (a) Hipotesis nihil $\left(\mathrm{H}_{0}\right)$, yang berbunyi 'data berdistribusi normal'; dan (b) Hipotesis alternatif (Ha), yang berbunyi 'data tidak berdistribusi normal'.

Uji normalitas dalam penelitian ini menggunakan Kolmogorov-Smirnov Test. Dari table 8 diketahui bahwa nilai Asymp. Sig. sebesar 0,00 (P-value < $0,05)$. Hal ini berarti data tidak berdistribusi normal. Dengan demikian, uji hubungan dilanjutkan dengan menggunakan metode nonparametrik Spearman Rank.

Pengambilan keputusan dalam uji hipotesis menggunakan derajat kepercayaan $(\alpha) 0,05$.

$$
\begin{aligned}
r h o & =1-\frac{6 \sum \mathrm{D}^{2}}{\mathrm{n}\left(\mathrm{n}^{2}-1\right)} \\
& =1-\frac{4(103532)}{115\left(115^{2}-1\right)} \\
& =0,5915
\end{aligned}
$$

Berdasarkan perhitungan uji korelasi Rank Spearman di atas, diperoleh hasil koefisien korelasi sebesar 0,592. Selanjutnya, dilakukan uji hipotesis. Perhitungan uji hipotesis dapat dilihat sebagai berikut.

$$
\begin{aligned}
z & =r_{s} \sqrt{n-1} \\
& =0,5915 \sqrt{115-1} \\
& =6,3158
\end{aligned}
$$

Perhitungan di atas kemudian dibandingkan dengan $\mathrm{z}$ tabel. Uji hipotesis dalam penelitian ini menggunakan uji 2 sisi (two-tailed) sehingga dalam uji 2 sisi interval keyakinan $(\alpha)$ dibagi dua yaitu $0,05 / 2$ menjadi 0,025. Dari tabel $\mathrm{z}$ diperoleh nilai $\mathrm{z}$ tabel sebesar 1,96. Batas kiri pengambilan keputusandengan kurva adalah $-1,96$ dan batas kanannya $+1,96$. Dari perhitungan tersebut didapat nilai $\mathrm{z}$ hitung adalah 6,316 ( $\mathrm{z}$ hitung $>\mathrm{z}$ tabel) sehingga $\mathrm{H}_{0}$ ditolak, ada hubungan yang signifikan antara perilaku merokok pada orang tua dan kejadian ISPA pada anak sekolah dasar.

\section{PEMBAHASAN \\ Hubungan Perilaku Merokok dengan Kejadian ISPA}

Kejadian ISPA tergolong tinggi ditemukan pada perokok berat atau mereka yang mengonsumsi rokok lebih dari 21 batang perhari. Dari segi intensitas merokok, tingginya orang tua yang tergolong perokok berat tersebut dapat dihubungkan dengan tingkat pendidikan para orang tua yang rendah. Dari data karakteristik diketahui bahwa sebagian besar orang tua hanya tamat Sekolah Dasar (SD) yaitu sebesar 53,9\%.

Hal ini didukung oleh penelitian dari Pradono \& Sulistyowati (2014) bahwa terdapat hubungan positif antara status kesehatan dengan tingkat pendidikan. Lindawati dkk (2012) menyebutkan bahwa terdapat hubungan yang bermakna antara pendidikan ibu dengan perilaku merokok. Responden yang ibunya berpendidikan tinggi memiliki kecendrungan 0,536 kali lebih kecil untuk merokok dibandingkan dengan responden yang ibunya berpendidikan rendah.

Zimmerman \& Woolf (2014) menjelaskan bahwa pendidikan menghasilkan keuntungan yaitu sampel cenderung memiliki hasil kesehatan yang lebih baik. Anak-anak dengan pendidikan dan kesehatan yang buruk berkaitan dengan perkembangan otak dan dampak patologis (Zimmerman \& Woolf (2014).

Sebagian besar orang tua telah merokok lebih dari 10 tahun, bahkan sebelum mereka menikah. Lamanya merokok ini disebabkan salah satunya oleh zat nikotin yang terdapat dalam rokok menyebabkan timbulnya efek ketagihan. Efek ketagihan dari nikotin berasal dari fungsinya dalam merangsang pembentukan dopamine yaitu senyawa kimia dalam otak yang menimbulkan perasaan senang. Menurut Sugito (2007) menyebutkan penelitian terkini menunjukkan bahwa pemakaian nikotin 
dalam waktu lama akan menurunkan kemampuan otak untuk mengenali perasaan senang yang sesungguhnya. Oleh sebab itu, para perokok biasanya menambah jumlah batang rokok yang dikonsumsi setiap harinya untuk memperoleh kenikmatan yang sama seperti saat pertama kali merokok dan cenderung sulit untuk menghentikan konsumsi rokok tersebut sehingga semakin lama kebiasaan merokok dilakukan, jumlah batang rokok yang dikonsumsi cenderung semakin banyak pula.

Pada perokok berat, kejadian ISPA lebih besar $11,7 \%$ yaitu sebesar 92,6\% dan pada golongan ini dijumpai kejadian ISPA anak tergolong tinggi sebesar 4,4\%, sedangkan pada non perokok tidak dijumpai. Hasil ini didukung oleh Candra (2014) yang menemukan hasil bahwa ayah perokok menyebabkan anak mudah terserang infeksi. Asap rokok mengandung gas-gas beracun yang dapat membuat rambut silia dalam sistem pernafasan rusak sehingga menyebabkan organisme patogen lebih mudah memasuki saluran nafas dan menimbulkan infeksi. Walaupun ISPA secara biologis disebabkan oleh patogen, namun perilaku merokok juga menjadi faktor risiko yang menyebabkan seseorang lebih mudah terkena ISPA.

Sebagian besar anak dengan orang tua perokok terkena ISPA sebanyak 4-6 kali dalam setahun yaitu sebesar 55,9\%. Pada hasil tersebut, diketahui bahwa pada orang tua yang merokok, anak mereka lebih sering mengalami kejadian ISPA dalam waktu 1 tahun. Menurut Ryadi \& Wijayanti (2011:11) terdapat 4 faktor risiko yang menyebabkan sakit yaitu predisposising factor, anabling factor, precipitating factor, re-enforcement factor. Perilaku merokok di sini dapat menjadi faktor precipitating dan re-enforcement. Pada precipitating factor, perilaku merokok menjadi salah satu faktor risiko penyebab terjadinya ISPA, yaitu paparan zat racun yang terkandung dalam asap rokok. Sedangkan pada re-enforcement factor, perilaku merokok menjadi salah satu faktor kejadian ISPA yang terulang, dimana orang tua yang merokok telah merokok sebagian besar selalu setiap hari selama lebih dari sepuluh tahun.

Asap rokok diperkirakan mengandung lebih dari 4000 senyawa kimia yang secara farmakologis terbukti aktif dan beracun yang dapat menyebabkan mutasi (mutagenic) dan kanker (carcinogenic). Di dalam Sugito (2007) dijelaskan bahwa tiga racun utama dalam rokok yaitu nikotin, tar dan karbon monoksida menyebabkan tersumbatnya pembuluh darah apabila terpapar dalam kurun waktu yang lama. Apabila pembuluh dara tersumbat, zat-zat yang dibutuhkan tubuh pun terhambat sehingga tubuh akan rentang mengalami ketidak-seimbangan. Ketidakseimbangan ini akan membuat tubuh lebih rentan terkena penyakit. Oleh sebab itu, kejadian Infeksi Saluran Pernapasan Atas anak pada orang tua yang merokok lebih besar dari orang tua yang tidak merokok.

Pada pengujian hipotesis, didapatkan hasil ada hubungan yang signifikan antara perilaku merokok orang tua dengan kejadian ISPA pada anak sekolah dasar usia 7-12 tahun di Puskesamas Porong. Perilaku merokok yang cenderung tinggi dapat dihubungkan dengan sebagian besar penduduk di wilayah kerja Puskesmas Porong adalah mereka dengan tingkat pendidikan cenderung rendah dan tingkat pendapatan yang sedang. Sebagian besar penduduknya juga bekerja dalam bidang swasta atau tidak terikat instansi yaitu sebagai buruh kasar.

Ada hubungan yang signifikan antara perilaku merokok pada orang tua dengan kejadian ISPA pada anak tersebut sesuai dengan New York State Department of Health (2014) bahwa pada anak-anak, asap rokok menyebabkan salah satunya adalah gejala pernapasan dan infeksi pernapasan. Prakasa (2015) menyebutkan bahwa asap rokok memiliki pengaruh terhadap jumlah leukosit total karena radikal bebas dan inflamasi. Ini berarti secara tidak langsung asap merokok dapat menurunkan sistem imun mereka yang menghisapnya sehingga 
menjadi lebih rentan terkena penyakit dari pada mereka yang tidak menghirup asap rokok.

Selain itu, hasil tersebut didukung oleh beberapa penelitian, diantaranya ada hubungan antara paparan asap rokok, perubahan mikrobioma, dan efek kesehatan yang merugikan (Jaspers et al, 2013). Ia juga mengungkapkan bahwa asap rokok secara langsung dapat memengaruhi ketahanan bakteri dan meningkatkan virulensi mereka. Paparan asap rokok juga mempengaruhi tingkat surfaktan yang mungkin juga berkontribusi terhadap imunitas host yang berubah (Mehta et al, 2008). Asap sebagai imunosupresan untuk fungsi sel kekebalan tubuh termasuk sel epitel pernafasan, makrofag, neutrofil dan limfosit.

Merokok memiliki efek lokal dan sistemik yang besar pada saluran pernapasan, sistem kekebalan tubuh dan kulit dan jaringan lunak, dan perubahan yang disebabkan dapat mengubah baik kerentanan terhadap infeksi maupun penyakit menular. Studi kontrol kasus dan perkiraan kematian akibat merokok menunjukkan efek buruk merokok terhadap kelangsungan hidup pada individu dengan penyakit menular (Huttunen et al, 2010). Paparan asap rokok ditemukan memengaruhi respons sel $\mathrm{T}$ pada paru-paru setelah infeksi eksperimental dengan $M$. tuberculosis, atau virus influenza, yang dikaitkan dengan peningkatan kemampuan bakteri dan peningkatan mortalitas (Feldman et al, 2013).

Dengan demikian, orang tua yang merokok, memiliki anak yang lebih rentan terkena ISPA daripada orang tua yang tidak merokok. Seperti penelitian serupa oleh Milo dkk (2015) bahwa ada hubungan antara kebiasaan merokok di dalam rumah dengan kejadian ISPA pada anak umur 1-5 tahun di Puskesmas Sario Kota Manado.

Anak-anak sebagai perokok pasif yang terpapar asap rokok juga dimungkinkan untuk terkena dampak yang sama dengan para perokok aktif. Hal ini didukung oleh penelitian
Benowitz et al (2010) yang menyatakan bahwa secara signifikan, mereka yang terkena asap rokok memiliki kadar cotinine/kreatinin yang juga tinggi dibanding perokok aktif. Hal ini dapat diartikan bahwa mereka yang tidak merokok juga berkemungkinan terkena dampak buruk dari merokok.

Dari segi keluarga, peranan orang tua menggambarkan seperangkat perilaku antar anggota, sifat, kegiatan yang berhubungan dengan anggota dalam posisi dan situasi tertentu. Pada usia sekolah dasar ini, anak lebih mudah meniru perilaku orang dewasa. Perilaku ayah yang merokok tidak mencerminkan perilaku kesehatan. Peran ayah menurut Jhonson \& Leny (2010) yaitu sebagai pencari nafkah, pendidik, pelindung, dan pemberi rasa aman, sebagai kepala keluarga, sebagai anggota dari kelompok sosialnya, serta sebagai anggota masyarakat dari lingkungannya. Dengan demikian, perilaku merokok tersebut tidak menunjukkan peran ayah dalam keluarga karena tidak mendidik anak dengan hal yang baik, dan tidak melindungi anak dari sakit karena membiarkannya terpapar zat racun yang terdapat dalam asap rokok tersebut. Dengan melihat ayah yang merokok, anak akan meniru perilaku tersebut meskipun dilarang oleh orang tuanya sehingga memunculkan perilaku negatif pada anak. Menurut Bala, dkk (2015), komunikasi terbuka digunakan orangtua dalam membimbing anak, menasehati dan memotivasi anak dalam pergaulannya setiap hari. Dan hal tersebut sudah menjadi peran, tugas dan fungsi orangtua dalam kehidupan berkeluarga sehingga orangtua harus mampu memberikan contoh dan teladan yang baik, apa yang dinasehatkan kepada anak sebaiknya dilakukan juga oleh orangtua.

Menurut Freeman dalam Jhonson \& Leny (2010), tugas keluarga dalam kesehatan salah satunya adalah mempertahankan suasana di rumah yang menguntungkan kesehatan dan perkembangan kepribadian anggota keluarga. Dengan perilaku merokok 
tersebut, orang tua tidak melaksanakan tugas keluarga dalam hal kesehatan dengan baik. Perilaku merokok sudah pasti bukanlah perilaku yang menciptakan suasana yang mendukung kesehatan anggota keluarga terutama pertumbuhan dan perkembangan anak. Orang tua akan memantau perkembangan dan kesehatan anak-anaknya, bahkan menjauhkannya dari asap rokok.

Permasalahan merokok memang menjadi persoalan yang cukup luas. Demikian pula dengan Rancangan Undang-Undang (RUU) tentang pertembakauan. RUU ini mengatur berbagai aspek yang mencakup budidaya, produksi, industri hasil tembakau, distribusi dan tata niaga yang sehat, serta pengendalian terhadap dampak konsumsi tembakau bagi kesehatan. Namun, pembahasan RUU Pertembakauan beberapa waktu lalu sempat memicu kontroversi.

Jika nantinya Rancangan UU Pertembakauan ini disahkan menjadi undang-undang, maka terdapat potensi pertambahan jumlah perokok di Indonesia. Dalam RUU tersebut, gambar mengenai bahaya rokok yang saat ini terdapat di bungkus rokok, akan ditiadakan. Padahal gambar di bungkus rokok itu telah diatur dalam UndangUndang Nomor 39 Tahun 2009 tentang Kesehatan dan Peraturan Pemerintah Nomor 109 tahun 2012 tentang Pengamanan Bahan yang Mengandung Zat Adiktif. RUU ini jelas akan bertentangan dengan beberapa undangundang yang lainnya.

RUU Pertembakauan diprotes antara lain karena sifatnya yang lintas sektoral dan jika disahkan akan membuat UU lain yang bersifat sektoral harus disesuaikan dengannya.

Ekonom Faisal Basri menyebut bahwa ada UU sektoral seperti UU Pertanian, UU Perindustrian, UU Penyiaran, UU Psikotropika dan lain-lain yang harus disesuaikan, seperti dinyatakan dalam pasal 70 RUUP yang menghendaki penyesuaian UU lain jika RUU Pertembakauan disahkan (BBC Indonesia, 2017).
Dalam RUU tersebut tujuan pengelolaan pertembakauan menempatkan peningkatan budidaya dan produksi tembakau di urutan pertama (Pasal 3), dan melindungi kesehatan masyarakat di urutan belakang. Pengelolaan pertembakauan juga mengusulkan pengesahan rencana induk budidaya tembakau dan pembangunan industri hasil tembakau (IHT) di pasal 5 (BBC Indonesia, 2017)

RUU tersebut juga memperbolehkan promosi oleh para pelaku usaha tembakau di berbagai media dengan pembatasan (pasal 48) (BBC Indonesia, 2017).

Hal ini menjadi kontroversial karena di berbagai negara, promosi rokok justru sedang mengalami pengurangan, bahkan penghilangan sama sekali guna menekan jumlah konsumen.

Beberapa hal yang menjadi kontroversial antara lain penyediaan ruang khusus (pasal 55) untuk perokok untuk kawasan tanpa asap rokok (seperti sekolah, rumah ibadah, rumah sakit dan sebagainya) yang dianggap menjadi alat untuk memfasilitasi para perokok, dan tidak adanya pernyataan bahwa produk tembakau seperti rokok merupakan zat adiktif.

Hal ini bertentangan dengan hasil dalam penelitian ini. Merokok adalah perilaku yang tidak sehat. Dalam hal ini, pemerintah harus menjadikan kesehatan sebagai prioritas utama untuk meningkatkan kesejahteraan masyarakat disamping dalam mempertimbangkan perekonomian. Di samping itu, RUU tersebut dapat menjadikan jumlah perokok di Indonesia meningkat.

Dalam hal ini peneliti tidak setuju terkait dengan pengesahan RUU Pertembakauan tersebut. DPR seharusnya juga mempertimbangkan bagaimana dampak jangka panjang apabila RUU tersebut disahkan. Pengesahan RUU seperti hanya untuk kepentingan meningkatkan perekomian Negara. Bagaimana pengusulan RUU oleh DPR yang meningkatkan produksi rokok sedangkan masyarakat dianjurkan untuk mengurangi bahkan menghentikan 
merokok. Beberapa pihak akan dirugikan tentang pelarangan merokok ataupun pelarangan produksi rokok. Namun, sangat banyak pihak pula yang dirugikan terkait dampak dari asap rokok.

Meskipun upaya anti merokok digencarkan di seluruh dunia, tetapi kebanyakan negara berkembang memiliki angka berhenti merokok yang rendah. Hasil monitoring dari Badan Konsumsi Tembakau di dunia, mencatat bahwa lebih dari 65 juta penduduk Indonesia adalah perokok aktif (Effendi, 2014). Indonesia juga tercatat sebagai negara ketiga di dunia setelah Cina, India, Rusia dan Amerika Serikat dengan tingkat konsumsi rokok teringgi di dunia. Tingginya angka perokok menyebabkan angka kematian oleh penyakit terkait tembakau di Indonesia tergolong tinggi. Pada tahun 2014, angka teratas perokok tertinggi adalah china dengan 390 juta perokok atau $29 \%$ per penduduk, India dengan 144 juta perokok atau $12,5 \%$ per penduduk, disusul Indonesia dengan 65 juta perokok atau $28 \%$ per penduduk, lalu Rusia dengan 61 juta perokok atau 43\% per penduduk, dan Amerika Serikat dengan 58 juta perokok atau $19 \%$ per penduduk (Effendi, 2014).

Dibanding negara-negara lain di dunia, Indonesia jelas tertinggal dalam upaya pengendalian rokok. Apalagi Indonesia termasuk dalam kelompok negara minoritas yang belum menandatangani Konvensi International Pengendalian Tembakau (Framework Convention of Tobacco Control), sebuah traktat yang dibuat untuk mengatur tembakau dan melindungi kesehatan masyarakat (Jamaluddin, 2015).

Tingginya tingkat konsumsi rokok di suatu negara berkorelasi dengan longgar atau ketatnya regulasi terhadap rokok (Darwin, 2007 dan Rachmat, 2010). Secara keseluruhan belum ditemukan di satu daerah pun di Indonesia yang telah menerapkan peraturan pembatasan perilaku merokok secara efektif. Indonesia masih merupakan tempat berbisnis rokok yang sangat menjanjikan bagi para industrialis rokok, menjadi surge bagi para perokok aktif karena mereka bebas merokok di tempat umum dan bagi mereka yang bukan perokok, harus mau bersabar. Hak asasi untuk terbebas dari asap rokok masih sulit untuk terlindungi karena para pembuat dan implementor kebijakan belum secara serius menegakkan peraturan.

Di Indonesia, perusahaanperusahaan rokok sangat bebas dan agresif memasarkan produk beracun tersebut, termasuk di antaranya adalah mempengaruhi dan memanfaatkan sektor perhotelan, restoran, cafe, kedai kopi, dan bar untuk mendukung kepentingan bisnisnya. Dalam pengendalian bahaya rokok, kebijakan yang ada di Indonesia dinilai relatif lebih kompromistis terhadap industri rokok (Rachmat, 2010:78). Di sisi lain, iklan-iklan rokok di Indonesia yang menjamur dimanamana dan sangat vulgar. Hampir di setiap sudut, bahkan di dekat sekolah, tempat ibadah, rumahsakit, iklan-iklan rokok sangat mudah ditemui. Padahal, di banyak negara, segala bentuk iklan rokok sudah dilarang, salah satunya di Uni Emirat Arab. Di Uni Emirat Arab tidak ada satu pun iklan rokok berupa papan billboard yang bisa ditemui di jalan (Jamaluddin, 2015). Undang-undang juga melarang seluruh TV dan media di Abu Dhabi untuk menayangkan iklan-iklan rokok.

\section{KESIMPULAN}

Berdasarkan hasil penelitian dan pembahasan, maka dapat disimpulkan bahwa ada hubungan yang signifikan antara perilaku merokok pada orang tua dengan kejadian ISPA pada anak sekolah dasar usia 7-12 tahun di Puskesmas Porong

\section{SARAN}

Berdasarkan kesimpulan yang telah diperoleh, saran yang dapat diberikan oleh peneliti yaitu perlunya mempertimbangkan faktor-faktor lain yang juga mempengaruhi kejadian sakit ISPA pada anak seperti status gizi dan rentangan usia anak yang lebih kecil, serta diharapkan terdapat penelitian lebih 
lanjut dengan memisahkan anak yang berusia 12 tahun dikarenakan pada usia tersebut, anak telah banyak terpengaruh lingkungan untuk melakukan kebiasaan merokok. Sebagai saran untuk masyarakat adalah agar orang tua yang memiliki anak usia sekolah dasar pada khususnya untuk tidak merokok di dalam

\section{DAFTAR RUJUKAN}

Azwar, Saifuddin. 2015. Penyusunan Skala Psikologi. Yogya karta: Pustaka Pelajar

Bala, ME., Senduk, J., Boham, A. 2015. Peran Komunikasi Keluarga dalam Mencegah Perilaku Merokok bagi Remaja di Kelurahan Winangun Keca matan Malalayang Kota Manado. E-Journal Acta Diurna, 4(3):1-11

Banlitbangkes. 2008. Riset Kesehatan Dasar (RISKESDAS) 2007: Laporan Nasional 2007. Jakarta: Departemen Kesehatan RI

Banlitbangkes. 2010. Riset Kesehatan Dasar: RISKESDAS 2010. Jakarta: Kementerian Kesehatan RI

Banlitbangkes. 2013. Riset Kesehatan Dasar: RISKESDAS 2013. Jakarta: Kementerian Kesehatan RI

BBC Indonesia. 2017. Yang Perlu Anda Tahu dari Kontroversi RUU Pertembakauan. (Online), (http://www.bbc.com/indone sia/indonesia-39179264) diakses 28 Juli 2017.

Benowitz, N., Goniewics, M., Eisner, MD., Lazcano-Ponca, E., Zielinska-Danch, W. Koszowski, N., Sobczak, A., Havel, Christopher., Jacob, P. 2010. Urine Cotinine Underestimates Exposure to the Tobacco-Derived Lung Carcinogen 4-(Methylnitros amino)-1-(3-Pyridyl)-1-But anone in Passive Compared with Active Smokers. American Asociation for rumah, menjaga jarak untuk merokok, tidak merokok di depan anak, dan dapat menghentikan kebiasaan merokok sedini mungkin. Hal ini, selain untuk meminimalkan dan menghilangkan paparan asap rokok juga sebagai contoh yang baik agar anak tidak meniru kebiasaan merokok orang tua tersebut.

Cancer Research, 19(11): 2795-2800.

Candra, A. 2014. Faktor Risiko Infeksi Pada Anak 1-2 Tahun. Journal of Nutrition and Health, 2(1):1-12.

Darwin, M. 2007. Perilaku Merokok dan Pengalaman Regulasi di Berbagai Negara. Populasi Journal, 18(2):201-215

Dinas Kesehatan Kebupaten Sidoarjo. 2013. Profil Kesehatan Kabupaten Sidoarjo Tahun 2013. (Online), (http://www. depkes.go.id), diakses 1 November 2016.

Dinas Kesehatan Kabupaten Sidoarjo. 2014. Profil Kesehatan Kabupaten Sidoarjo Tahun 2014. (Online), (http://www. depkes.go.id), diakses 19 Oktober 2016.

Dinas Kesehatan Kabupaten Sidoarjo. 2015. Profil Kesehatan Puskesmas Sidoarjo Tahun 2015. (Online), (http:// dinkes.sidoarjokab.go.id), diakses 1 November 2016.

Effendi, T. 2014. Indonesia Peringkat 3 di Dunia. (Online), (http: //www.kompasiana.com/ jiptadinataeffendi21may 43) diakses 3 Agustus 2017

Fieldman, C., Anderson, R. 2013. Cigarette Smoking and Mechanisms of Susceptibility to Infections of The Respiratory Tract and Other Organ Systems. Journal of Infection, 5(4):169-184.

Fitria., Triandhini, R., Mangimbulude, JC., Karwur, FF. 2013. Merokok dan Oksidasi DNA. Sains Medika, 5(2): 120-127. 
Hartini, H., Fatimah, S., Mardhiyah, A. 2012. Tipe Perilaku Merokok pada Remaja Perokok di SMP Negeri 1 Jatinangor. Jurnal Keperawatan, 1(1):1-15.

Huttunen, R., Heikkinen, T., Syrjanen, J. 2010. Smoking and The Outcome of Infection. Journal of Internal Medicine, 1(1):258-269.

Jamaluddin, M. 2015. Indonesia, Surga Industri Rokok. (Online), (http://www.kompasiana.co $\mathrm{m}$ /masrurjamaluddin) diakses 3 Agustus 2017

Jaspers, I. 2013. Cigarette Smoke Effects on Innate Immune Mechanisms in The Nasal Mucosa: Potential Effects on the Microbiome. The American Thoracic Society (AnnalsATS), 11(1):38-42.

Jhonson \& Leny. 2010. Keperawatan Keluarga: Plus Contoh Askep Keluarga. Yogya karta: Nuha Medika.

Marni. 2014. Asuhan Keperawatan pada Anak dengan Gangguan Pernapasan. Yogyakarta: Gosyen Publishing.

Mehta, H., Sadikot, RT. 2008. Cigarette Smoking and Innate Immunity. National Center for Biotechnology Infor mation, U.S. National Library of Medicine, 57(11):497-503.

Milo, S., Ismanto, AY., Kallo, VD. 2015. Hubungan Kebiasaan Merokok di Dalam Rumah dengan Kejadian ISPA pada Anak Umur 1-5 Tahun di Puskesmas Sario Kota Monado. Ejournal Kepe rawatan, 3(2):1-7.

New York State Department of Health. 2014. Secondhand Smoke Kills. (Online), (https:// www.health.ny.gov/), diakses 16 Oktober 2016.

Noviyanti \& Zulaekah. 2010. Hubungan Asupan Energi, Protein,
Besi, Seng Dengan Status Imunitas Anak Balita Di Perkampungan Kumuh Kota Surakarta. Jurnal Kesehatan, 3(2):129-139.

Pradono \& Sulistyowati. 2014. Hubungan antara Tingkat Pendidikan, Pengetahuan Tentang Kesehatan Lingkungan, Perilaku Hidup Sehat dengan Status Kesehatan. Buletin Penelitian Sistem Kesehatan, 17(1) :89-95.

Prakarsa, A.B. 2015. Pengaruh Madu terhadap Jumlah Leukosit Total yang Dipapari Asap Rokok. Jurnal Majority, 4(7):73-76.

Puskesmas Porong. 2015. Profil Kesehatan Puskesmas Porong Tahun 2015: Gambaran Derajat Kesehatan Masyarakat di Wilayah Puskesmas Porong Tahun 2015. Puskesmas Porong.

Putra, L. 2017. RUU Pertembakauan Dinilai Bertentangan dengan 14 Undang-Undang. (Online), (http://nasional.kompas.com /) diakses 28 Juli 2017

Rachmat, M. 2010. Pengembangan Ekonomi Tembakau Nasional: Kebijakan Negara Maju dan Pembelajaran bagi Indonesia. Analisis Kebi jakan Pertanian, 8(1):67-83

Ramadhan, N. 2012. Hubungan Ibu Hamil Perokok Pasif dengan Kejadian Bayi Berat Lahir Rendah di Badan Layanan Umum Daerah RSU Meuraxa Banda Aceh. Jurnal Ilmiah STIKES U'Budiyah, 1(2):27-34.

Ryadi \& Wijayanti. 2011. Dasar-dasar Epidemiologi. Jakarta: Salemba Medika.

Sugito, J. 2007. Stop Rokok. Jakarta: Penebar Swadaya

Sundari, R., Widjaya, D.S., \& Nugraha, 


\begin{abstract}
A. 2015. Lama Merokok dan Jumlah Konsumsi Rokok terhadap Trombosit pada Laki-laki Perokok Aktif. Jurnal Kesehatan Masyarakat Nasional, 9(3):257-263.
\end{abstract}

United for Lung Health: Forum of International Respiratory Societies. 2013. Respiratory Diseases in the world Realities of Today -
Opportunities

for

Tomorrow.

(Online),

(https://www.ersnet.org),

diakses 29 Oktober 2016.

Zimmerman, E., Woolf, S. 2014. Understanding the Relationship Between Education and Health. Discussion Paper. Institute of Medicine: Washington DC 